\title{
The Atrophy of the Professional Role among Teachers from Middletown in Poland. An Analysis of the Phenomenon and Its Determinants
}

\section{Łukasz Kutyło}

University of Łódź, Faculty of Economics and Sociology, Department of Sociology of Politics and Morality

\section{Abstract}

The subject matter of this paper is the phenomenon of atrophy of the professional role among teachers. The term 'atrophy' must be understood as the gradual disappearance of duties binding upon the individual that regulate his/her professional role. In the case of schools, this phenomenon results in the noticeable decrease in teachers' professional commitment, which makes it difficult or even impossible for these institutions to fulfil their educational and other goals. Sources of the atrophy of the professional role should be sought not only in the individual, his/her mindsets or attitude to work, but also in the environment in which he/she functions. The weakening of intermediary structures seems to play an important role in this process. These are cognitive scripts that potentially increase the likelihood that the individual will be inclined to comply with the duties of which his/her professional role consists. These structures are formed as a result of factors such as the impact of the mechanisms of social control on the individual. For the purpose of verifying this assumption, a survey was conducted among teachers $(N=131)$ from three primary schools from Middletown in Poland. The analysis of data acquired from this survey shows that the atrophy of the professional role may be influenced by the weakening of these structures that are responsible for the formation of the sense of the purpose of work being performed and the creation of the normative distance.

Key words: atrophy of professional role; intermediary structures; professional commitment; professional role; social norms; teachers. 


\section{Introduction}

The phenomenon of the atrophy of the professional role is one of the threats to the efficient functioning of educational institutions. This concept must be understood as the gradual disappearance of duties binding upon the individual that regulate his/her professional role. Considering the work performed by academic teachers, Braxton, Bayer, and Noseworthy (2004) remarked that, although the teachers have a certain degree of autonomy in fulfilling their duties, there are certain patterns of behaviour that they are required and expected to follow - for example, in order to protect the well-being of students themselves. A set of these duties forms a certain normative structure (Braxton \& Bayer, 1999). The survey they conducted shows that teachers' non-compliance with the duties inscribed in their role has an impact on the involvement of students in learning and their satisfaction with studies (Braxton, Bayer, \& Noseworthy, 2004). There is a well-founded assumption that a similar situation also takes place at earlier stages of education. The duties forming this structure could be treated as a sort of capital that enables the school to fulfil its collective goals relating to education. Its level would specify to what extent teachers working in this school comply with the obligations inscribed in their professional role.

Thus, the atrophy on which we focus in this paper makes it impossible or difficult to create this capital. The following chart shows how this phenomenon can manifest itself in the case of teachers. Their professional role (which is symbolised by a square here) consists of a set of certain duties (represented by white circles). The progress of atrophy leads to the situation when a given teacher gives up fulfilling these duties to an increasingly large extent (which is shown by the growing number of black circles on the following chart). This phenomenon seems to be influenced significantly by the weakening of these cognitive representations, called here intermediary structures, which are responsible for the activation and maintenance of duties inscribed in the teacher's professional role. Thus, there are two concepts of essential importance for our further reflections: duties and intermediary structures. Let us start by looking at the first of them.

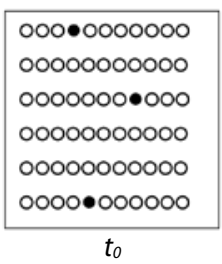

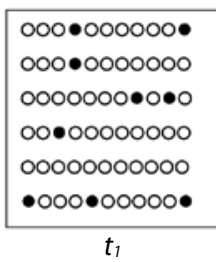

Figure 1. The process of atrophy of the professional role
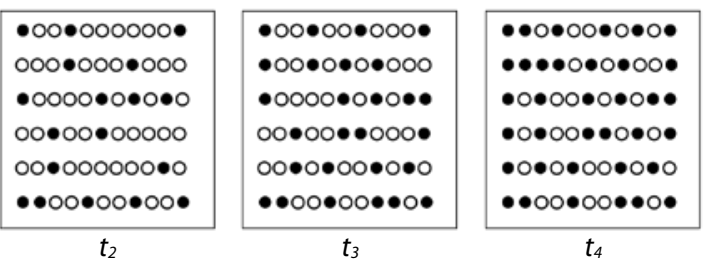

The concept of duty refers to the socially expected pattern of behaviour - something that is usually defined as a social norm in sociology. A number of misunderstandings have arisen in connection with this term, making it unclear and ambiguous. Not only is it used in colloquial speech, but various definitions of the norm are formed in 
individual academic fields of study (Bicchieri, 2005, 2010). The starting point for the opinion presented in the paper was a certain manner of understanding this term. It would be worth starting the exploration of this subject from what has been defined as normative expectation. This concept is understood as the pattern of behaviour that the individual is expected to follow in a certain situation. However, this pattern cannot be called a social norm until: (a) it is disseminated among members of a specific community in the form of a cognitive script for the expected behaviour developed by them and (b) its fulfilment will not be guaranteed by certain mechanisms of social control (e.g., social sanctions). The normative expectation turns into a social norm thanks to influences that make up the institutionalisation process. At that time, a certain social consensus is formed with regard to the expected pattern of behaviour - i.e., a majority of members of the community considers it proper and desirable to follow this pattern (Braxton, 2010, p. 243; Horne, 2001, p. 5). They also feel, to a greater or smaller extent, that it is their duty to comply with this pattern (Hechter \& Opp, 2001, pp. xii-xiii).

The institutionalisation of the norm leads to the formation of certain intermediary structures within the individual. Their name comes from the fact that they play an intermediary role between the expected pattern and the actual behaviour. These structures increase the likelihood that the individual will be inclined to follow the social norm. They are formed by various kinds of cognitive scripts that trigger a certain mode within the individual that is ultimately responsible for the activation and maintenance of the given pattern of behaviour. Altogether, three such modes have been distinguished, largely on the basis of the typology of subjective norms present in the subject literature (that reflect the individual's beliefs concerning the rules that govern him/her and social life) (Lapinski \& Rimal, 2005). The first of these modes, called the personal mode, is based on structures that develop a sense of the purpose of adherence to the given pattern of behaviour in the individual (or playing a certain social role by him/her). They build the conviction that this will make it possible to keep the values that are important for the individual. However, it must be stressed that neither the concept of the personal mode nor the concept of structures of which it consists are fully identical to the concept of personal norm used in the literature of the subject. According to Schwartz (1977), personal norms exist irrespective of social norms. They are related to the conception of oneself. They form a set of individual standards by means of which people autonomously regulate their behaviour. They make it possible to express the values that are important for the individual (see also Bamberg et al., 2007, pp. 190-192; Kallgren et al., 2000). In the context of our analysis, however, such understanding of the personal norm seems to be limited and largely determined by psychological reductionism. It is difficult not to agree with Etzioni, who suggests that, in spite of their individualised character, such patterns of behaviour are internalised social norms to a large extent (Etzioni, 2000, pp. 161-164). However, even if we assume the definition of the personal norm extended with this remark, 
this concept is still not fully identical to the personal mode. This mode, along with structures forming it, does not have to lead to the internalisation of the normative expectation. The individual can be aware of its exogenic character. Moreover, it seems that the structures forming this mode do not have to refer to duties (e.g., moral obligations) - their role is only to shape the sense of reasonableness of the behaviour inscribed in the given norm (or role).

The second mode - the injunctive mode - consists of structures that make the individual feel that the fulfilment (or non-fulfilment) of the socially expected pattern of behaviour will meet with a certain reaction from the social environment. However, the concept of the injunctive mode is not fully identical to the concept of injunctive norm. It is suggested in the subject literature that the injunctive norm reflects the individual's belief that the social environment requires him/her to follow a certain pattern of behaviour (Cialdini et al., 1990, p. 1015; Morris et al., 2015, p. 3). This definition remains partly coherent with how the social norm is generally understood on the basis of this conception, however, on the assumption that this expectation is really formulated towards the individual (and exists not only in his/her imagination) and he/she does not have to be aware of its exogenic character. However, the belief that the social environment requires something from us - an inherent factor of the injunctive norm - emphasises the essence of the injunctive mode and structures forming it: the social responsiveness of social norms (Elster, 2007). The fulfilment of duties inscribed in them - or, on the contrary, failure to fulfil them - usually meets with a positive or negative reaction of the environment that assumes the form of stimuli reinforcing the given behaviour or aversive stimuli that discourage it.

And, finally, there is the descriptive mode. The structures forming it develop the individual's belief that other members of the community comply with the given social norm. Again, this concept is not fully identical to the concept of descriptive norm. The descriptive norm reflects the individual's conviction about behaviours that commonly occur in a given community. This conviction defines what is typical and normal in this community (Lapinski \& Rimal, 2005, p. 130). If the individual is not aware of the rules governing the given social environment, descriptive norms shorten the decisionmaking process by informing him/her what kind of behaviour will allow them to adapt to the existing circumstances (Cialdini et al., 1990, p. 1015; Cialdini, 2001). On the other hand, the descriptive mode along with its structures shapes the individual's conviction to what extent norms expected in the community are actually followed in it. Incidentally, it defines the normative distance, i.e., the discrepancy between his/her own behaviour and the behaviour of other members of the community.

If the expectation forming the norm is to be fulfilled, it is enough to activate at least one of these modes. The institutionalisation process shaping intermediary structures and activating these modes is largely based on mechanisms of social control. They can be discursive or non-discursive. Among the former, we can mention role models that deliver a description of individuals capable of achieving certain values 
along with their typical repertoires of behaviour (Lockwood et al., 2002, pp. 854-856; Merton, 1957), which inspire others to act (Morgenroth et al., 2015) and model the proper way of playing the role (Eriksson-Zetterquist, 2008, pp. 260-262). Currently, they are disseminated mainly via mass media (Ilić et al., 2017, p. 6; Lindenberg et al., 2011, pp. 98-100). Another example of discursive mechanisms are group prototypes, which are responsible for the formation of social identity and influence individuals' conceptions of themselves (Tajfel \& Turner, 1986). They consist, among other things, of representations of the social norms prevailing in a given community, which emphasise similarities between its members on the one hand and distinguish the community itself from other social categories on the other hand (Hogg \& Reid, 2006, pp. 9-22; Reynolds et al., 2014; Turner et al., 1999). Social sanctions are an example of non-discursive mechanisms. In the subject literature, mainly negative sanctions are emphasised. The risk of their use increases when a violation of the norm is not in the interest of the person observing this and affects his/her sense of responsibility or when the norm is violated by a member of this community (Brown, 1995; Chekroun \& Brauer, 2002; Forsyth, 1995).

Referring these reflections to the phenomenon of atrophy of the professional role among teachers, which means the gradual disappearance of duties inscribed in it, we can say that the likelihood of its occurrence seems to grow when: (a) they lose the sense of purpose of playing it; (b) and/or they are no longer afraid of negative sanctions to be imposed by the environment in the case of failing to meet their expectations (or, on the contrary, they see no chance of positive sanctioning of their behaviour); (c) and/or they perceive that other teachers do not comply with the norms that regulate their professional role. It is reasonable then to formulate the following hypothesis:

Hypothesis: The higher the degree to which the weakening of intermediary structures can be observed in the case of a teacher covered by the survey, the less inclined s/he will be to follow the norms regulating their professional role.

In other words, there is a well-founded assumption that the deactivation of indicated modes leads to atrophy. For the purpose of looking at this phenomenon more closely, a survey was conducted in three public primary schools in Middletown in Poland.

\section{Methodology}

\section{Participants}

The survey was conducted in Middletown in Poland - a city where the number of inhabitants ranges from 50,000 to 100,000 . For this survey, three primary schools were selected by drawing lots (they were called Schools A, B and C). The survey itself was conducted by means of a hand-out questionnaire in May 2018. Questionnaires were delivered to schools, and each of them was provided with an envelope where the questionnaire could be hidden after being filled in. It was decided that this kind of strategy would guarantee a higher sense of safety to respondents, considering that 
a part of the questions referred to their commitment to work or evaluation of the school board. Persons managing the selected schools were excluded from the survey. Moreover, the survey did not cover the teachers who were on sick leave. Respondents had two weeks to fill in the questionnaire and leave it in a sealed envelope in the school secretary's office. The survey covered a total number of 131 respondents. It turned out, however, that some questionnaires had not been filled in completely. As a result of this, they were excluded from further analyses. Finally, 120 questionnaires were obtained (respectively: 42 from School A, 34 from School B and 44 from School C). It is worth mentioning that women accounted for a prevailing majority of respondents $(\mathrm{N}=97$; 83.6\%). Moreover, most teachers covered by the survey were in a relationship (e.g. married) at that time $(\mathrm{N}=94 ; 78.3 \%)$, had worked at school for more than 20 years $(\mathrm{N}=73 ; 60.8 \%)$, were employed on a full-time basis $(\mathrm{N}=112 ; 93.3 \%)$, and were not working at any other school than the one where the survey was conducted $(\mathrm{N}=109$; 90.8\%).

\section{Measures}

In order for the hypothesis verification to be possible, it became necessary to operationalise the concepts present in it, including norms regulating the professional role of the teacher and intermediary structures.

\section{Norms Regulating the Professional Role}

The operationalisation of the first concept was possible thanks to a preliminary survey conducted among 25 teachers employed in primary schools in the Łódź province. They were asked to choose a maximum of 15 expectations referring to them in a previously prepared questionnaire. Then their task was to choose the ones that they considered to be the most important in a teacher's work. Eventually, 13 such norms were defined. They indicated that a person working in the profession concerned should: be prepared for the lesson; keep documentation in an orderly manner; be able to maintain discipline in the classroom; explain the issues that pupils cannot understand; find time when a pupil's parent/guardian needs something from him/her; treat his/her pupils in a fair manner (never play favourites); find time to help pupils when they do not understand something; discover talents, abilities and predispositions in his/her pupils; be able to convey knowledge to pupils in a manner that they find convenient; broaden his/her knowledge regarding his/her subject; treat pupils with respect; be able to arouse enthusiasm for learning in them; appreciate pupils' efforts, even if they do not result in good marks.

It was decided that the degree of the respondent's non-compliance with norms regulating his/her professional role would be measured by means of a question beginning with the following instruction: Below you will find several statements. Please think to what extent they describe the work that you perform. Please refer to them using the scale from -3 to 3 , where -3 means that you strongly disagree with the given statement, 
and 3 means that you strongly agree with the given statement. A certain problem arose in the pilot study. It turned out that if the statements reflected the content of previously defined norms too literally (e.g., 'I broaden my knowledge about the subject that I teach'), respondents showed a tendency to mark almost only categories suggesting their full compliance with duties. It was assumed that this partiality of answers proves the normativeness of the statements. Due to the fact that the fulfilment of patterns of behaviour resulting from them is secured with certain sanctions, respondents were unwilling to admit that they had violated indicated norms. Thus, the content of statements was modified in such a way that respondents could relatively safely admit that the given expectation was not being fulfilled. For example, the aforementioned statement: 'I broaden my knowledge about the subject that I teach' was transformed as follows: 'I do not have time for broadening my knowledge about the subject that I teach.' It contained the rationalisation of the behaviour that did not comply with the norm and allowed respondents to save face when this expectation was not being fulfilled by the given respondent. Data from the proper survey indicate that the scale built in this way proved reliable. The value of Cronbach's alpha was $\alpha=0.863$ here. This scale was used for measuring the average level of compliance with norms (regulating the professional role of the teacher). The value of this variable was within the range from -3 to 3 . The higher it was, to the larger extent the given respondent complied with norms regulating the role of the teacher.

\section{The Sense of Purpose}

It was also necessary to operationalise intermediary structures. At the beginning of the survey, the researcher focused on the scripts that develop a sense of purpose of the role being fulfilled in the individual. It was decided that this feeling arises when certain needs become satisfied, including both lower-level and higher-level needs. Altogether, the indicated variable was measured using 10 statements to which the respondent was asked to respond on a scale from -3 to 3 where -3 meant that he/ she strongly disagreed with the given statement and 3 meant that he/she strongly agreed with it. Thus, the respondents were to determine whether working as a teacher gives them: a possibility of professional development; a sense of professional safety; an opportunity to develop their passions and hobbies; an opportunity to fulfil their professional vocation; the joy of being in touch with children and young people; an opportunity to educate and develop young people; a sort of social prestige and the feeling of being appreciated by others; whether this work is financially satisfactory to them and whether they have much spare time (for themselves and their families). The scale built in this way proved to be reliable. The value of Cronbach's alpha was $a=0.723$. It was used for measuring the variable $a$ sense of purpose of the role being fulfilled. The subject matter of the analysis was its average value, which ranked in the range from -3 to 3 . The higher it was, the more strongly the respondent felt that his/ her work made sense. 


\section{Negative and Positive Responsiveness}

The measurement of intermediary structures activating the injunctive mode was carried out using two questions reflecting the individual's belief how likely it is that: (a) the violation of the aforementioned norms will meet with a negative reaction from the environment (the school board, other teachers); (b) compliance with these rules will be accompanied by positive sanctions. Both questions referred to the previously defined patterns of behaviour, and the respondent was to determine the likelihood of the negative/positive reaction on the scale from -3 to 3 . Both scales proved reliable. The value of Cronbach's alpha was $\alpha=0.903$ in the first case and $\alpha=0.898$ in the second case. Thus, these scales were used for measuring the following variables: responsiveness of the environment to the violation of norms and responsiveness of the environment to compliance with norms. The subject matter of the analysis was their average values, which ranked in the range from -3 to 3 . The higher they were, the more strongly the respondent felt that the violation of the norm or compliance with it involves the higher responsiveness from the environment (positive/negative responsiveness).

\section{Compliance with Norms by Others}

Intermediary structures responsible for the activation of the descriptive mode were measured in a similar manner. This was done by means of 13 statements referring to pre-defined norms regulating the teacher's role. The respondent was asked to determine to what extent these statements describe the manner of performance of professional duties by other teachers from his/her school. The question opening this subject area contained information that it lays emphasis on the general feeling that accompanies the respondent rather than a detailed evaluation of his/her work that would require an in-depth analysis and reflection. When determining to what extent a certain pattern of behaviour is common in his/her school, the respondent used the scale from -3 to 3 , where -3 meant that the given description did not match teachers from his/her school at all, whereas 3 meant that it fully reflects their manner of fulfilment of professional duties. The scale built in this way proved reliable. The value of Cronbach's alpha was $\alpha=0.836$. This scale was used for measuring the variable: compliance with norms by others. The subject-matter of the analysis covered its average value, which ranked in the range from -3 to 3 . The higher it was, the more strongly the respondent felt that teachers from his/her school complied with indicated norms.

\section{Data Analysis}

The obtained data were entered into the SPSS program. In the first place, it was analysed to what extent the phenomenon under discussion affects schools covered by the survey. For the purpose of checking if the average level of teachers' compliance with the norms regulating their professional role is different in these schools, a one-way analysis of variance (ANOVA) was used. This method was also applied in the evaluation of differences that potentially exist between schools with regard 
to teachers' compliance with individual norms and the strength of intermediary structures influencing them. In order for the verification of the hypothesis to be possible, a multiple linear regression model was built, where the dependent variable was the average level of teachers' non-compliance with the norms regulating their professional role, and independent variables included the sense of purpose of the role being performed, responsiveness of the environment to the violation of norms (negative responsiveness), responsiveness of the environment to compliance with norms (positive responsiveness) and compliance with norms by others. Before the regression analysis and the final evaluation of the model were carried out, independent variables present in this model had been correlated.

\section{Results}

At the beginning, an analysis of the extent the phenomenon of atrophy affects these three schools from Middletown was performed. It was assumed that: The average level of non-compliance with the norms regulating the role of teacher is different among teachers working in these three schools selected for the survey. For the purpose of identifying differences between them in this respect, a one-way analysis of variance (ANOVA) was used. According to the data gathered, the indicated institutions were affected by the aforementioned phenomenon only to a small extent. The average level of teachers' compliance with norms regulating their professional role seems to be high, because it reached the mean value $=1.00$. Post hoc tests (NIR and Bonferroni tests) showed that a statistically important $(p<0.01)$ difference in the amount of this variable exists between teachers from School A $($ Mean $=1.23)$ and School C $($ Mean $=0.78)$. The detailed data in this regard are presented in Table 1.

Table 1

The average level of teachers' compliance with norms regulating their professional role depending on school ( $N=117)$

\begin{tabular}{|c|c|c|c|c|c|c|c|c|}
\hline \multicolumn{5}{|c|}{ Descriptive statistics } & \multicolumn{4}{|c|}{ One-way analysis of variance } \\
\hline School & $\mathrm{N}$ & Mean & SD & SE & ANOVA & $\mathrm{df}$ & $\mathrm{F}$ & $p$ value \\
\hline School A & 42 & 1.23 & 0.66 & 0.10 & BS & 2 & 5.25 & 0.01 \\
\hline School B & 34 & 1.01 & 0.60 & 0.11 & WS & 114 & & \\
\hline School C & 44 & 0.78 & 0.64 & 0.10 & Total & 116 & & \\
\hline Total & 117 & 1.00 & 0.66 & 0.06 & & & & \\
\hline
\end{tabular}

The analysis also covered the extent to which respondents complied with the norms taken into account in the survey. It turned out that the duties inscribed in the professional role that were fulfilled to the largest extent concerned: keeping documentation, treating pupils with respect, appreciating their effort, finding time for them, preparing for lessons, and discovering talents, abilities and predispositions in their pupils. It seems that the biggest problems are the fulfilment of norms obliging teachers to maintain discipline in the classroom and to arouse enthusiasm for learning in their pupils. Table 2 presents data concerning this issue according to the schools covered by the survey. 
Kutyto: The Atrophy of the Professional Role among Teachers from Middletown in Poland. An Analysis ...

Table 2

Compliance with individual norms by teachers from schools covered by the survey $(N=117)$

\begin{tabular}{|c|c|c|c|c|}
\hline PROFESSIONAL NORMS: & SCHOOL A & SCHOOL B & SCHOOL C & TOTAL \\
\hline - preparing for the lesson & 2.05 & 1.76 & 1.79 & 1.87 \\
\hline - keeping documentation & 2.50 & 2.00 & 2.18 & 2.24 \\
\hline - maintaining discipline in the classroom & 0.14 & -0.06 & -0.39 & -0.11 \\
\hline $\begin{array}{l}\text { - explaining the issues that pupils cannot } \\
\text { understand }\end{array}$ & 0.83 & 1.09 & 0.48 & 0.77 \\
\hline $\begin{array}{l}\text { - finding time when a pupil's parent/ } \\
\text { guardian needs something }\end{array}$ & 1.21 & 0.91 & 0.89 & 1.01 \\
\hline - treating pupils in a fair manner & 0.50 & 0.50 & 0.11 & 0.36 \\
\hline $\begin{array}{l}\text { - finding time to help pupils, when they } \\
\text { do not understand something }\end{array}$ & 2.28 & 1.36 & 0.66 & 1.43 \\
\hline $\begin{array}{l}\text { - discovering talents, abilities and } \\
\text { predispositions in pupils }\end{array}$ & 1.59 & 1.21 & 1.04 & 1.28 \\
\hline $\begin{array}{l}\text { - conveying knowledge to pupils in a } \\
\text { manner that they find convenient }\end{array}$ & -0.05 & 0.35 & 0.16 & 0.14 \\
\hline $\begin{array}{l}\text { - broadening their knowledge regarding } \\
\text { the subject }\end{array}$ & 0.78 & 0.88 & 0.54 & 0.72 \\
\hline - treating pupils with respect & 2.33 & 1.68 & 1.45 & 1.82 \\
\hline $\begin{array}{l}\text { - arousing enthusiasm for learning in } \\
\text { pupils }\end{array}$ & -0.09 & -0.32 & -0.20 & -0.20 \\
\hline $\begin{array}{l}\text { - appreciating pupils' efforts, even if they } \\
\text { do not result in good marks }\end{array}$ & 1.93 & 1.56 & 1.48 & 1.66 \\
\hline
\end{tabular}

The conception presented in the theoretical part suggests that intermediary structures have a significant impact on the individual's compliance or non-compliance with norms regulating his/her professional role. Therefore, these structures became the focus of attention. The analysis showed that the sense of purpose of the role being performed is relatively high among teachers covered by the survey. Similarly, they obtained relatively high scores in the measurement of: responsiveness of the environment to the violation of social norms (negative responsiveness) and compliance with norms by others. They were convinced to the smallest extent that the fulfilment of patterns of behaviour regulating their professional role would result in positive sanctions (including reinforcing stimuli, such as respect in the environment, praise, etc.). For the purpose of finding differences within the scope of these structures that potentially exist between teachers from schools covered by the survey, a one-way analysis of variance (ANOVA) was used. Interestingly enough, in the case of variables such as: responsiveness of the environment to the violation of norms or responsiveness of the environment to compliance with norms, differences between schools turned out to be statistically insignificant $(p>0.05)$. A slightly different situation occurred when the sense of purpose of the role being performed was analysed. Post hoc tests (NIR and Bonferroni tests) showed that the difference in the amount of this variable between teachers from School A (mean = 1.34) and from 
School C (mean $=0.96)$ is statistically significant $(p<0.05)$. The same situation took place for the variable compliance with norms by others. The same post hoc tests showed that the difference in the amount of this variable between teachers from School A $($ mean $=1.10)$ and School C $($ mean $=0.30)$ is statistically significant $(p<0.05)$. Data concerning results of the analysis are presented in Table 3.

Table 3

Average values of variables reflecting intermediary structures depending on school

\begin{tabular}{|c|c|c|c|c|c|c|c|c|c|}
\hline \multirow{2}{*}{$\begin{array}{l}\text { Intermediary } \\
\text { structures }\end{array}$} & \multicolumn{5}{|c|}{ Descriptive statistics } & \multicolumn{4}{|c|}{ One-way analysis of variance } \\
\hline & School & $\mathrm{N}$ & Mean & SD & SE & ANOVA & $\mathrm{df}$ & $\mathrm{F}$ & $\mathrm{p}$ value \\
\hline \multirow{4}{*}{$\begin{array}{l}\text { Sense of } \\
\text { purpose }\end{array}$} & A & 41 & 1.35 & 0.67 & 0.10 & BS & 2 & 3.48 & 0.03 \\
\hline & B & 34 & 1.19 & 0.76 & 0.13 & WS & 116 & & \\
\hline & $C$ & 44 & 0.96 & 0.59 & 0.09 & Total & 118 & & \\
\hline & Total & 119 & 1.16 & 0.68 & 0.06 & & & & \\
\hline \multirow{4}{*}{$\begin{array}{l}\text { Negative } \\
\text { responsiveness }\end{array}$} & A & 40 & 1.24 & 1.26 & 0.20 & BS & 2 & 0.15 & 0.86 \\
\hline & B & 34 & 1.16 & 1.34 & 0.23 & WS & 115 & & \\
\hline & $C$ & 44 & 1.32 & 1.31 & 0.20 & Total & 117 & & \\
\hline & Total & 118 & 1.24 & 1.29 & 0.12 & & & & \\
\hline \multirow{4}{*}{$\begin{array}{l}\text { Positive } \\
\text { responsiveness }\end{array}$} & A & 42 & 0.13 & 0.78 & 0.12 & BS & 2 & 0.50 & 0.61 \\
\hline & B & 34 & 0.10 & 0.81 & 0.14 & WS & 117 & & \\
\hline & $C$ & 44 & -0.02 & 0.68 & 0.10 & Total & 119 & & \\
\hline & Total & 120 & 0.07 & 0.75 & 0.07 & & & & \\
\hline \multirow{4}{*}{$\begin{array}{l}\text { Compliance } \\
\text { with norms by } \\
\text { others }\end{array}$} & A & 40 & 1.10 & 0.84 & 0.13 & BS & 2 & 11.89 & 0.01 \\
\hline & B & 34 & 0.41 & 0.74 & 0.13 & WS & 115 & & \\
\hline & $C$ & 44 & 0.30 & 0.81 & 0.12 & Total & 117 & & \\
\hline & Total & 118 & 0.60 & 0.87 & 0.08 & & & & \\
\hline
\end{tabular}

The verification of the research hypothesis required the elaboration of the linear regression model where the dependent variable was the average level of noncompliance with norms regulating the professional role. It was created as a result of recoding the value of the variable compliance with these norms. The model covered also potential predictors of this value that reflect previously mentioned intermediary structures, including: the sense of purpose of the role being performed, responsiveness of the environment to the violation of norms (negative responsiveness), responsiveness of the environment to compliance with norms (positive responsiveness), compliance with norms by others.

At the beginning, the type of relationships between independent variables were analysed. It turned out that there is a moderate correlation between the sense of purpose of the role being performed, responsiveness of the environment to compliance with norms (positive responsiveness) and compliance with norms by others. The detailed data in this regard are presented in Table 4. 
Kutyto: The Atrophy of the Professional Role among Teachers from Middletown in Poland. An Analysis ...

Table 4

Results of the correlation of independent variables included in the linear regression model

\begin{tabular}{llcccc}
\hline \multicolumn{2}{c}{ Independent variables: } & $\begin{array}{c}\text { Sense of } \\
\text { purpose }\end{array}$ & $\begin{array}{c}\text { Negative } \\
\text { responsiveness }\end{array}$ & $\begin{array}{c}\text { Positive } \\
\text { responsiveness }\end{array}$ & $\begin{array}{c}\text { Compliance with } \\
\text { norms by others }\end{array}$ \\
\hline $\begin{array}{l}\text { Sense of } \\
\text { purpose }\end{array}$ & Pearson correlation & 1 & -0.01 & 0.25 & 0.29 \\
& Two-sided sign. & & 0.92 & 0.01 & 0.01 \\
Negative & N & 119 & 117 & 119 & 117 \\
responsiveness & Pearson correlation & -0.01 & 1 & -0.04 & 0.12 \\
& Two-sided sign. & 0.92 & & 0.70 & 0.22 \\
Positive & N & 117 & 118 & 118 & 116 \\
responsiveness & Pearson correlation & 0.25 & -0.04 & 1 & 0.21 \\
& Two-sided sign. & 0.01 & 0.70 & & 0.02 \\
Compliance & $\mathrm{N}$ & 119 & 118 & 120 & 118 \\
with norms by & Pearson correlation & 0.29 & 0.11 & 0.21 & 1 \\
others & Two-sided sign. & 0.01 & 0.22 & 0.02 & \\
\hline
\end{tabular}

Finally, the results of the analysis of the multiple linear regression were analysed. For this purpose, the backward elimination method was used, on the assumption that the ultimate model should contain independent variables that are significantly related to the dependent variable. The results of the analysis show that predictors of non-compliance with norms regulating the professional role are: the sense of purpose of the role being performed and compliance with norms by others. The relationship existing between the dependent variable and the sense of purpose of the role being performed turned out to be moderate and negative. Here, Pearson's correlation coefficient was $r$ $=-0.261(p<0.01)$. The relationship existing between the dependent variable and the compliance with norms by others turned out to be high and negative. Here, Pearson's correlation coefficient was $r=-0.553(p<0.01)$. The more strongly the respondents were convinced that their work makes no sense and other teachers in their school do not comply with the norms concerned, the less likely it was that they submitted to the expectations inscribed in their professional role. The predictive value of the model is big. The adjusted coefficient of determination was $R^{2}=0.45$. This means that the model explains 45 per cent of the variance of the dependent variable. Table 5 presents detailed results of the regression analysis.

The obtained results at least partly confirmed the research hypothesis. They indicate that the weakening of intermediary structures responsible for the sense of purpose of work and for the conviction of compliance with norms by other teachers contributes to what was called the atrophy of the professional role. 
Table 5

Results of modelling the relationship between non-compliance with norms regulating the teacher's professional role and variables reflecting intermediary structures

\begin{tabular}{|c|c|c|c|c|c|c|c|c|c|c|c|c|}
\hline \multirow{2}{*}{ Predictors: } & \multicolumn{4}{|c|}{ MODEL I } & \multicolumn{4}{|c|}{ MODEL II } & \multicolumn{4}{|c|}{ MODEL III } \\
\hline & B & SE & Beta & $p$ & B & SE & Beta & $p$ & B & SE & Beta & $P$ \\
\hline Constant & -0.41 & 0.11 & & 0.01 & -0.41 & 0.11 & & 0.01 & -0.44 & 0.10 & & 0.01 \\
\hline $\begin{array}{l}\text { Sense of } \\
\text { purpose }\end{array}$ & -0.26 & 0.08 & -0.26 & 0.01 & -0.26 & 0.07 & -0.26 & 0.01 & -0.26 & 0.07 & -0.26 & 0.01 \\
\hline $\begin{array}{l}\text { Negative } \\
\text { responsiveness }\end{array}$ & -0.03 & 0.04 & -0.06 & 0.43 & -0.03 & 0.04 & -0.06 & 0.44 & & & & \\
\hline $\begin{array}{l}\text { Positive } \\
\text { responsiveness }\end{array}$ & -0.02 & 0.07 & -0.02 & 0.83 & & & & & & & & \\
\hline $\begin{array}{l}\text { Compliance } \\
\text { with norms }\end{array}$ & -0.41 & 0.06 & -0.54 & 0.01 & -0.41 & 0.05 & -0.55 & 0.01 & -0.41 & 0.05 & -0.55 & 0.01 \\
\hline $\mathrm{R}$ & \multicolumn{4}{|c|}{0.68} & \multicolumn{4}{|c|}{0.68} & \multicolumn{4}{|c|}{0.68} \\
\hline $\mathrm{R}^{2}$ & \multicolumn{4}{|c|}{0.46} & \multicolumn{4}{|c|}{0.46} & \multicolumn{4}{|c|}{0.46} \\
\hline Adjusted $\mathrm{R}^{2}$ & \multicolumn{4}{|c|}{0.44} & \multicolumn{4}{|c|}{0.45} & \multicolumn{4}{|c|}{0.45} \\
\hline
\end{tabular}

\section{Discussion}

The survey shows that the weakening of intermediary structures activating the descriptive mode and the personal mode may have a statistically significant impact on teachers' non-compliance with norms regulating their role. In the first case, the individual has a well-founded or unjustified conviction that other teachers from his/her school do not submit to the existing expectations. It seems that even if the individual is willing to comply with these norms, there is a problem assuming the form of a growing normative distance. This is because he/she perceives to an increasing extent the difference between his/her own behaviour and patterns of behaviour shown in the social environment. This results in cognitive dissonance, due to which maintaining the normative distance becomes costly. Therefore, if the teacher is convinced that other persons working in his/her school do not comply with norms regulating the professional role, it is very likely that he/she will stop fulfilling them, too. The significant impact of such beliefs on behaviour was empirically shown in experimental studies (Cialdini et al., 1990; Kallgren et al., 2000).

Atrophy also seems to be stimulated by the weakening of structures responsible for the formation of the sense of purpose of the role being performed. This involves a series of questions concerning, e.g., the extent to which school as an organisation participates in this process. If we assume that a society organises the behaviour of its members by means of social control mechanisms, including the subtler ones that affect their personal beliefs and attitudes, the collapse or underestimation of these mechanisms may lead to the weakening of the society's ability to give sense to certain activities. Social possibilities regarding the activation and maintenance of structures 
activating the personal mode become limited. In such case, the individual needs to create the sense of playing his/her role in himself/herself. The survey shows that, in the case of teachers, the reinforcement of such intermediary structures occurs, among others, thanks to positive sanctions that they can expect from their environment.

The analysis did not cover other factors that are likely to have a smaller or larger impact on the phenomenon of atrophy. For example, it is likely that the fulfilment of norms inscribed in the role may be endangered by occupational burnout or fatigue, which is a consequence of excessive expectations regarding work or the professional burden (Sas et al., 2011; Springer \& Oleksa, 2017). In the context of obtained results, reflections made by Herczyński and Strawiński (2014) seem interesting, too. On the basis of data from an empirical study conducted on a large sample of teachers in Polish schools, they separated a number of smaller groups: support-dependent, professionals, workaholics, young enthusiasts and burnouts. Apart from burnouts, bigger problems concerning the fulfilment of duties inscribed in the role may also appear in representatives of two other groups. They can include, e.g., teachers from the supportdependent group. The study does not specify clearly who its representatives are. Thus, the authors proposed two possible characteristics of these teachers. According to one of them, they are not engaged in school work; they may be considering a change of job, and they may think that the fulfilment of their professional duties is a waste of time. On the other hand, there is presumption that these persons feel comfortable in the teaching profession and devote as much time to their work as they are required. The second group is burnouts, who - in comparison to others - feel more heavily burdened with work and have a weaker sense of purpose of its performance (Herczyński \& Strawiński, 2014, pp. 34-36).

Finally, the analysis did not cover factors concerning the management and organisation of work in schools. Assuming that intermediary structures are largely created as a result of structural impacts, taking account of these issues could enrich reflections on atrophy. The analysis of the data obtained allowed us to observe statistically significant differences in the level of compliance with norms depending on the school in which respondents worked. Thus, there is a likelihood that the activation of individual modes may depend on relationships existing between teachers and between them and the school board or pupils. It would be worth considering whether intermediary structures and the fulfilment of obligations inscribed in the professional role are influenced by the ineffective post-feudal organisational culture described by Hryniewicz, which is typical of countries of Central and Eastern Europe and may exist at least in some Polish schools (Hryniewicz, 2007).

\section{Conclusions}

The aim of the survey was to identify the determinants of atrophy in three primary schools from Middletown in Poland. It was assumed that the weakening of intermediary structures between the pattern of behaviour and the individual's actual 
behaviour should have a significant impact on teachers' non-compliance with norms regulating their professional role. The results of the survey show that the larger the deactivation of the personal mode, consisting of structures developing a sense of purpose of the professional role being performed in the teacher, and the descriptive mode, which is based on structures defining the normative distance, the more inclined he/she will be to fail to comply with duties inscribed in the role.

Although atrophy is a desirable process when individual behaviours are organised in a dysfunctional manner, this phenomenon is usually negative because it hinders the creation of such normative capital that would be favourable for the fulfilment of collective goals in the community or society. Thus, it seems reasonable to define factors that have an impact on the weakening of intermediary structures and to specify to what extent this process depends on schools and on work organisation methods applied in them.

\section{References}

Bamberg, S., Hunecke, M., \& Blöbaum, A. (2007). Social context, personal norms and the use of public transportation: Two field studies. Journal of Environmental Psychology, 27(3), 190-203. https://doi.org/10.1016/j.jenvp.2007.04.001

Bicchieri, C. (2005). The grammar of society: The nature and dynamics of social norms. Cambridge: Cambridge University Press. https://doi.org/10.1017/CBO9780511616037

Bicchieri, C. (2010). Norms, preferences and conditional behavior. Politics, Philosophy \& Economics, 9(3), 297-313. https://doi.org/10.1177/1470594X10369276

Braxton, J. M., \& Bayer, A. E. (1999). Faculty misconduct in collegiate teaching. Baltimore: Johns Hopkins University Press.

Braxton, J. M., Bayer, A. E., \& Noseworthy, J. A. (2004). The influence of teaching norm violations on the welfare of students as clients of college teaching. The Journal of Higher Education, 99, 41-46. https://doi.org/10.1002/tl.157

Brown, R. (1995). Prejudice: Its social psychology. Cambridge: Cambridge University Press.

Chekroun, P., \& Brauer, M. (2002). Reactions to norm violations and the number of bystanders: Evidence for the bystander effect in social control behavior. European Journal of Social Psychology, 32, 853-867. https://doi.org/10.1002/ejsp.126

Cialdini, R. B., Reno, R. R., \& Kallgren C. A. (1990). A focus theory of normative conduct: Recycling the concept of norms to reduce littering in public places. Journal of Personality and Social Psychology, 58(6), 1015-1026. https://doi.org/10.1037/0022-3514.58.6.1015

Elster, J. (2007). Explaining social behavior: More nuts and bolts for social sciences. Cambridge: Cambridge University Press. https://doi.org/10.1017/CBO9780511806421

Eriksson-Zetterquist, U. (2008). Gendered role modelling - A paradoxical construction process. Scandinavian Journal of Management, 24(3), 259-270. https://doi.org/10.1016/j. scaman.2008.05.002 
Etzioni, A. (2000). Social norms: internalization, persuasion, and history. Law \& Society, 34(1), 157-178. https://doi.org/10.2307/3115119

Forsyth, D. R. (1995). Norms. In A. S. R. Manstead, \& M. Hewstone (Eds.), The Blackwell Encyclopedia of Social Psychology (pp. 412-417). Oxford: Blackwell.

Hechter, M., \& Opp, K. (2001). Introduction. In M. Hechter, \& K. Opp (Eds.), Social Norms (pp. xi-xix). New York: Russel Sage.

Herczyński, J., \& Strawiński, P. (2014). Postawy zawodowe nauczycieli: próba typologii. Edukacja, 3(128), 22-37.

Hogg, M. A., \& Reid, S. A. (2006). Social identity, self-categorization, and the communication of group norms. Communication Theory, 16(1), 7-30. https://doi.org/10.1111/j.14682885.2006.00003.x

Horne, Ch. (2001). Sociological perspectives on the emergence of norms. In M. Hechter, \& K. Opp (Eds.), Social Norms (pp. 3-34). New York: Russel Sage.

Hryniewicz, J. (2007). Stosunki pracy w polskich organizacjach. Warszawa: Wydawnictwo Naukowe Scholar.

Ilić, I. S., Blažanin B., \& Mojović K. (2017). Public figures as role models of Serbian adolescents: Who are idols and why? Serbian Political Thought, 15(1), 5-20. https://doi. org/10.22182/spt.1512017.1

Kallgren, C. A., Reno, R. R., \& Cialdini, R. B. (2000). A focus theory of normative conduct: When norms do and do not affect behavior. Personality and Social Psychology Bulletin, 26(8), 1002-1012. https://doi.org/10.1177/01461672002610009

Lapinski, M. K., \& Rimal, R. N. (2005). An explication of social norms. Communication Theory, 15, 127-147. https://doi.org/10.1111/j.1468-2885.2005.tb00329.x

Lindenberg, S., Joly, J. F., \& Stapel, D. A. (2011). The norm-activating power of celebrity: The dynamics of success and influence. Social Psychology Quarterly, 74(1), 98-120. https://doi. org/10.1177/0190272511398208

Lockwood, P., Jordan C. H., \& Kunda Z. (2002). Motivation by positive and negative role models: Regulatory focus determines who will best inspire us. Journal of Personality and Social Psychology, 83(4), 854-864. https://doi.org/10.1037/0022-3514.83.4.854

Merton, R. K. (1957). Social theory and social structure. New York: Free Press.

Morgenroth, T., Ryan, M. K., \& Peters, K. (2015). The motivational theory of role modelling: How role models influence role aspirants' goals. Review of General Psychology, 19(4), 1-19. https://doi.org/10.1037/gpr0000059

Morris, M. W., Hong, Y. Y., Chiu, C. Y., \& Liu, Z. (2015). Normology: Integrating insights about social norms to understand cultural dynamics. Organizational Behavior and Human Decision Processes, 129, 1-13. https://doi.org/10.1016/j.obhdp.2015.03.001

Reynolds, K. J., Subašić, E., \& Tindall, K. (2014). The problem of behavior change: From social norms to an ingroup focus. Social and Personality Psychology Compass, 10(1), 1-12. https://doi.org/10.1111/spc3.12155

Sas, C., Boros, D., \& Bonchis, E. (2011). Aspects of the burnout syndrome within the teaching staff. Procedia - Social and Behavioral Sciences, 11, 266-270. https://doi.org/10.1016/j. $\underline{\text { sbspro.2011.01.074 }}$ 
Schwartz, S. H. (1977). Normative influences on altruism. In L. Berkowitz (Ed.), Advances in Experimental Social Psychology (Vol. 10) (pp. 221-279). New York: Academic Press. https:// doi.org/10.1016/S0065-2601(08)60358-5

Springer, A., \& Oleksa, K. (2017). Praca emocjonalna a wypalenie zawodowe - analiza porównawcza pracy nauczycieli i pracowników sektora usług komercyjnych. Medycyna Pracy, 68(5), 605-615.

Tajfel, H., \& Turner, J. C. (1986). The social identity theory of intergroup behavior. In S. Worchel, \& W. G. Austin (Eds.), Psychology of intergroup relations (pp. 7-24). Chicago: Nelson Hall.

Turner, J. C. (1999). Some current issues in research on social identity and self-categorization theories. In N. Ellemers, R. Spears, \& B. Doosje (Eds.), Social identity: context, commitment, content (pp. 6-34). Oxford: Blackwell Publishers Ltd.

\section{Łukasz Kutyło}

University of Łódź, Faculty of Economics and Sociology

90-214 Łódź, St. Rewolucji 1905 nr 41/43, Poland

lukas.kutylo@gmail.com 


\section{Atrofija profesionalne uloge među nastavnicima iz grada srednje veličine u Poljskoj. Analiza fenomena i njegove odrednice}

\section{Sažetak}

Tema je ovoga rada atrofija profesionalne uloge među nastavnicima. Termin „atrofija“ mora se shvatiti kao postupno nestajanje dužnosti koje su za pojedinca obvezujuće i koje reguliraju njegovu ili njezinu profesionalnu ulogu. Kada se radi o školama, taj fenomen ima za rezultat primjetno smanjenje profesionalnih obveza nastavnika, što predstavlja prepreku obrazovnim institucijama u postizanju obrazovnih $i$ drugih ciljeva. Izvori atrofije profesionalne uloge ne bi se trebali tražiti samo u nastavnicima, njihovu načinu razmišljanja ili njihovim stavovima prema poslu, nego i u okruženju u kojemu rade. Čini se da slabljenje intermedijarnih struktura ima važnu ulogu u tom procesu. Intermedijarne strukture kognitivni su scenariji koji mogu povećati vjerojatnost da će pojedinac biti sklon izvršavanju obveza od kojih se sastoji njegova profesionalna uloga. Ti scenariji nastaju kao rezultat čimbenika kao što je utjecaj mehanizama društvene kontrole na pojedinca. Kako bi se ta pretpostavka potvrdila, provedeno je istraživanje među nastavnicima $(T=131)$ triju osnovnih škola iz grada srednje veličine u Poljskoj. Analiza podataka dobivenih ovim istraživanjem pokazuje da na atrofiju profesionalne uloge može utjecati slabljenje struktura koje su odgovorne za razvoj osjećaja svrhe u poslu koji pojedinac obavlja i nastanak normativne distance.

Ključne riječi: atrofija profesionalne uloge; intermedijarne strukture; predanost poslu.

\section{Uvod}

Atrofija profesionalne uloge jedan je od fenomena koji predstavlja prijetnju učinkovitome funkcioniranju obrazovnih institucija. Taj pojam treba shvatiti kao postupno nestajanje dužnosti koje su za pojedinca obvezujuće i koje reguliraju njegovu ili njezinu profesionalnu ulogu. Uzimajući u obzir rad sveučilišnih profesora, Braxton, 
Bayer i Noseworthy (2004) su primijetili da, iako nastavnici imaju određeni stupanj autonomije u obavljanju svojega posla, ipak postoje neki obrasci ponašanja koji se od njih zahtijevaju i očekuju kako bi, na primjer, u prvi plan stavili dobrobit svojih učenika. Skupina takvih zaduženja čini određenu normativnu strukturu (Braxton i Bayer, 1999). Istraživanje koje su proveli pokazuje da neobavljanje dužnosti koje se od nastavnika očekuju utječe na angažiranost učenika u učenju i na njihovo zadovoljstvo učenjem (Braxton, Bayer i Noseworthy, 2004). Postoji dobro utemeljena pretpostavka da se slična situacija može uočiti i u ranijim fazama obrazovanja. Zaduženja koja sačinjavaju takvu strukturu mogla bi se smatrati svojevrsnim kapitalom koji školi omogućava ispunjenje kolektivnih ciljeva vezanih uz obrazovanje, a njezina bi razina mogla odrediti koliko nastavnici koji rade u toj školi poštuju obveze koje su uključene u njihovu profesionalnu ulogu.

Dakle, atrofija na koju ćemo se fokusirati u ovome radu onemogućava ili otežava stvaranje takvoga kapitala. Sljedeći prikaz prikazuje kako se taj fenomen može manifestirati kod nastavnika. Njihova profesionalna uloga (koja je ovdje prikazana kvadratom) sastoji se od skupine određenih zaduženja (prikazanih bijelim krugovima). Razvoj atrofije vodi situaciji kada određeni nastavnik odustaje od izvršavanja tih dužnosti u sve većoj mjeri (što je prikazano sve većim brojem crnih krugova na prikazu). Čini se da na taj fenomen uvelike utječe slabljenje kognitivnih reprezentacija, koje ovdje nazivamo intermedijarnim strukturama, a koje su odgovorne za aktiviranje i stalno izvršavanje dužnosti koja sačinjavaju nastavnikovu profesionalnu ulogu. Tako se može reći da postoje dva pojma koja su od ključne važnosti za naša daljnja razmatranja: dužnosti i intermedijarne strukture. Započet ćemo s prvom od njih.

\section{Prikaz 1}

Pojam dužnosti odnosi se na obrazac ponašanja koje društvo očekuje - na nešto što se u sociologiji obično definira kao društvena norma. Mnogi su nesporazumi nastali $\mathrm{u}$ vezi s tim terminom te ga učinili nejasnim i dvosmislenim. Ne samo da se koristi u kolokvijalnom govoru nego postoje i različite definicije norme u pojedinačnim akademskim područjima istraživanja (Bicchieri, 2005, 2010). Polazište za stav prikazan u ovome radu bio je određeni način na koji se termin koristi. Bilo bi korisno započeti istraživanje te teme sa stajališta normativnih očekivanja, koja se shvaćaju kao obrazac ponašanja koje bi pojedinac trebao imati u određenoj situaciji. Međutim, taj obrazac ponašanja ne može se nazvati društvenom normom sve dok: (a) se ne proširi među članovima određene zajednice u obliku kognitivnog scenarija za očekivano ponašanje, a koji su oni sami izradili i (b) se njegovo izvršenje ne jamči određenim mehanizmima društvene kontrole (npr. društvenim sankcijama). Normativno očekivanje prelazi u društvenu normu zahvaljujući utjecajima koji sačinjavaju institucionalizirani proces. Tada se stvara određeni društveni konsenzus u vezi s očekivanim obrascem ponašanja - npr. većina članova zajednice smatra dobrim i poželjnim da se takav obrazac održi (Braxton, 2010, str. 243; Horne, 2001, str. 5). Također smatraju, u većoj ili manjoj mjeri, da je njihova dužnost da s njim budu suglasni (Hechter i Opp, 2001, str. xii-xiii). 
Institucionalizacija norme vodi izgradnji određenih intermedijarnih struktura kod osobe. Njihov naziv proizlazi iz činjenice da imaju intermedijarnu (posrednu) ulogu između očekivanog ponašanja i stvarnoga ponašanja. One povećavaju vjerojatnost da će osoba biti sklona poštivanju društvene norme, a izgrađuju ih različite vrste kognitivnih scenarija koji pokreću određeni način ponašanja pojedinca koji je odgovoran za aktiviranje i usvajanje zadanog obrasca ponašanja. Sveukupno postoje tri takva načina ponašanja, a uvelike se temelje na tipologiji subjektivnih normi (one odražavaju uvjerenja osobe o pravilima koja ga vode i koja upravljaju njegovim društvenim životom) koje se mogu pronaći u literaturi koja se bavi tom tematikom (Lapinski i Rimal, 2005). Prvi način ponašanja, koji nazivamo osobni način, temelji se na strukturama koje kod osobe razvijaju osjećaj svrhe u poštivanju zadanoga obrasca ponašanja (ili kada ima određenu društvenu ulogu). One uvjeravaju osobu da će moći zadržati vrijednosti koje su joj bitne. Međutim, potrebno je naglasiti da ni pojam osobnog načina ni pojam struktura od kojih se on sastoji nisu identični pojmu osobne norme koja se koristi u relevantnoj literaturi. Prema Schwartzu (1977), osobne norme postoje neovisno o društvenim normama. Povezane su sa slikom koju imamo o sebi, a tvore skupinu osobnih standarda s pomoću kojih ljudi autonomno reguliraju svoje ponašanje. Omogućavaju nam da izrazimo vrijednosti koje su nam bitne (vidi Bamberg i sur., 2007, str. 190-192; Kallgren i sur., 2000). U kontekstu naše analize, međutim, takvo poimanje osobne norme čini se ograničenim i uvelike određenim psihološkim redukcionizmom. Teško je ne složiti se s onime što je naveo Etzioni, koji smatra da su takvi oblici ponašanja uglavnom internalizirane društvene norme, usprkos individualnim osobinama (Etzioni, 2000, str. 161-164). Međutim, čak i ako pretpostavimo da je definicija osobne norme ovom opaskom proširena, pojam još uvijek nije isti kao osobni način. Takav način, zajedno sa strukturama koje ga oblikuju, ne mora voditi internacionalizaciji normativnih očekivanja. Osoba može biti svjesna svojega egzogenog karaktera. Štoviše, čini se da se strukture koje izgrađuju taj način ponašanja uopće ne moraju odnositi na dužnosti (moralne obveze, npr.) - njihova je uloga samo oblikovati osjećaj razumnoga ponašanja od kojega se zadana norma (ili uloga) sastoji.

Drugi način - nametnuti način ponašanja - sastoji se od struktura koje u osobi stvaraju osjećaj da će poštivanje ili nepoštivanje društveno očekivanog obrasca ponašanja u društvenom okruženju izazvati određenu reakciju. Međutim, pojam nametnutog načina ponašanja nije istoznačan s pojmom nametnute norme. $U$ literaturi koja se bavi tom tematikom navodi se da nametnuta norma odražava uvjerenje osobe da društveno okruženje od njega/nje očekuje poštivanje određenoga obrasca ponašanja (Cialdini i sur., 1990, str. 1015; Morris i sur., 2015, p. 3). Ta je definicija i dalje djelomično u skladu s načinom na koji se društvena norma uglavnom shvaća na temelju te predodžbe, no pod pretpostavkom da očekivanja od neke osobe zaista postoje (ne postoje samo imaginarno) i da ta osoba ne mora biti svjesna njihova egzogenog karaktera. Međutim, uvjerenje da društveno okruženje zahtijeva nešto 
od nas - što je sastavni faktor nametnute norme - naglašava samu bit nametnutog načina ponašanja i struktura koje ga oblikuju: društveni odgovor na društvene norme (Elster, 2007). Izvršavanje dužnosti od kojih se one sastoje ili, suprotno tome, njihovo neizvršavanje, obično u društvenom okruženju izaziva pozitivnu ili negativnu reakciju. Ta reakcija poprima oblik podražaja koji potiče ponašanje prema zadanom obrascu ili suprotnoga podražaja koji odvraća osobu od nepostupanja prema zadanom obrascu ponašanja.

Konačno, postoji i deskriptivan način ponašanja. Strukture koje ga oblikuju izgrađuju uvjerenja osobe da drugi članovi zajednice poštuju zadanu društvenu normu. Taj pojam nije istoznačan s pojmom deskriptivne norme. Deskriptivna norma odražava uvjerenja koje osoba ima o ponašanju koje se često vidi u određenoj zajednici. To uvjerenje definira što je tipično i normalno u toj zajednici (Lapisnki i Rimal, 2005, str. 130). Ako osoba nije svjesna pravila koja vrijede u određenom društvenom okruženju, deskriptivne norme skraćuju proces donošenja odluka tako što je informiraju o tome kakva će joj vrsta ponašanja omogućiti prilagodbu postojećim okolnostima (Cialdini i sur., 1990, str. 1015; Cialdini, 2001). S druge strane, deskriptivan način, zajedno sa svojim strukturama, oblikuje uvjerenja osobe o tome koliko se norme koje su očekivane u nekoj zajednici uistinu i poštuju. Osim toga, on definira i normativnu distancu, tj. razliku između vlastitog ponašanja neke osobe i ponašanja drugih članova zajednice.

Ako je potrebno poštivati očekivanja sadržana u normi, dovoljno je aktivirati barem jedan od tih triju načina. Proces institucionalizacije koji oblikuje intermedijarne strukture i aktivira te načine ponašanja uglavnom se temelji na mehanizmima društvene kontrole, koji mogu biti diskurzivni ili nediskurzivni. Što se tiče prvih, možemo spomenuti uzore koji su utjelovljenje opisa osoba koje mogu ostvariti određene vrijednosti svojim tipičnim oblicima ponašanja (Lockwood i sur., 2002, str. 854-856; Merton, 1957), koji su inspiraciju drugima i potiču ih na djelovanje (Morgenroth i sur., 2015) i model su ispravnog načina postupanja u skladu s ulogom (Eriksson-Zetterquist, 2008, str. 260-262). U današnje se vrijeme diskurzivni mehanizmi šire uglavnom putem masovnih medija (Ilić i sur., 2017, str. 6; Lindenberg i sur., 2011, str. 98-100). Još jedan primjer su prototipovi skupine, koji su odgovorni za stvaranje društvenoga identiteta i koji utječu na sliku koju osoba ima o sebi (Tajfel i Turner, 1986). Između ostaloga, sastoje se i od reprezentacije društvenih normi koje prevladavaju u određenoj zajednici, a koje naglašavaju sličnosti između svojih članove s jedne strane, a s druge strane razlikuju samu zajednicu od ostalih društvenih kategorija (Hogg i Reid, 2006, str. 9-22; Reynolds i sur., 2014; Turner i sur., 1999). Društvene sankcije primjer su nediskurzivnih mehanizama. U relevantnoj literaturi naglašavaju se uglavnom negativne sankcije. Rizik njihove primjene povećava se kada nepoštivanje neke norme nije $\mathrm{u}$ interesu osobe koja proces promatra i kada to utječe na njezin osjećaj odgovornosti, ili kada normu krši član te zajednice (Brown, 1995; Chekroun i Brauer, 2002; Forsyth, 1995). 
Gledajući na to sve u kontekstu atrofije profesionalne uloge među nastavnicima, što znači postupno nestajanje dužnosti koje ona sadržava, možemo reći da je vjerojatnost da će do nje doći veća kada nastavnici: (a) izgube smisao svrhe te uloge; (b) i/ili se više ne boje negativnih sankcija okoline ako ne ispune njezina očekivanja (ili, suprotne tome, ne vide mogućnost pozitivnog sankcioniranja svojega ponašanja); (c) i/ili smatraju da ostali nastavnici ne poštuju norme koje reguliraju njihovu profesionalnu ulogu. Stoga je razumno postaviti sljedeću hipotezu:

Hipoteza: Što se u većoj mjeri slabljenje intermedijarnih struktura može primijetiti kod nastavnika koji sudjeluje u ovom istraživanju, to će oni biti manje skloni poštivanju normi koje reguliraju njihovu profesionalnu ulogu.

Drugim riječima, postoji dobro utemeljena pretpostavka da deaktivacija navedenih načina ponašanja vodi atrofiji. Kako bismo pobliže ispitali taj fenomen, provedeno je istraživanje u tri državne osnovne škole u gradu srednje veličine u Poljskoj.

\section{Metodologija}

\section{Sudionici}

Istraživanje je provedeno u gradu srednje veličine u Poljskoj - gradu u kojem broj stanovnika varira između 50000 i 100000 . Za ovo istraživanje slučajnim odabirom odabrane su tri osnovne škole (Škole A, B i C). Samo istraživanje provedeno je s pomoću upitnika koji su podijeljeni sudionicima u svibnju 2018. godine. Upitnici su dostavljeni školama, a uz svaki je uručena i omotnica u koju se upitnik nakon popunjavanja mogao spremiti. Odlučeno je da će takva strategija jamčiti višu razinu sigurnosti ispitanicima, uzimajući u obzir činjenicu da se dio pitanja odnosi na njihovu predanost poslu ili na procjenu rada školskog odbora. Osobe koje upravljaju odabranim školama nisu bile uključene $u$ istraživanje. Isto tako, istraživanje nije uključivalo nastavnike koji su bili na bolovanju. Ispitanici su imali dva tjedna za popunjavanje upitnika i ostavili su ih u zatvorenim omotnicama u uredu tajnice škole. Istraživanje je obuhvatilo ukupno 131 ispitanika. Međutim, pokazalo se da neki upitnici nisu potpuno popunjeni. Zbog toga su bili isključeni iz daljnje analize. Na kraju je dobiveno 120 upitnika (i to: 42 iz škole A, 34 iz škole B i 44 iz škole C). Važno je napomenuti da je većina ispitanika bila ženskog spola ( $\mathrm{T}=97 ; 83,6 \%)$. Nadalje, većina nastavnika uključenih u istraživanje nisu bili samci, nego u vezi (npr. u braku) ( $\mathrm{T}=94 ; 78,3 \%$ ), radili su u školi više od 20 godina ( $\mathrm{T}=73 ; 60,8 \%$ ), bili su zaposleni na neodređeno, puno radno vrijeme $(\mathrm{T}=112 ; 93,3 \%)$ te nisu radili ni u jednoj drugoj školi osim u onoj u kojoj je istraživanje provedeno ( $\mathrm{T}=109 ; 90,8 \%$ ).

\section{Mjerenja}

Kako bi se mogla provesti provjera hipoteze, bilo je neophodno operacionalizirati pojmove prisutne u njoj, uključujući norme koje reguliraju profesionalnu ulogu nastavnika i intermedijarne strukture. 


\section{Norme koje reguliraju profesionalnu ulogu}

Operacionalizacija prvog pojma bila je moguća zahvaljujući preliminarnom istraživanju koje je provedeno na uzorku od 25 nastavnika zaposlenih u osnovnim školama u okrugu Łódź. Trebali su u prije pripremljenom upitniku odabrati najviše 15 očekivanja koja se na njih odnose. Sljedeći je zadatak bio da odaberu one za koje su smatrali da su najvažnija u radu nastavnika. Na kraju je definirano 13 takvih normi. Naznačili su da osoba koja radi u nastavničkoj profesiji treba: biti pripremljena za nastavni sat; voditi uredno dokumentaciju; moći održati disciplinu u razredu; objasniti ono što je učenicima teško razumjeti; naći vremena kada ih roditelj/skrbnik djeteta treba; postupati prema svim učenicima jednako (nemati omiljene učenike); naći vrijeme kako bi pomogli učenicima kada nešto ne razumiju; otkriti u učenicima talente, sposobnosti i predispozicije; moći prenijeti znanje učenicima na njima odgovarajući način; proširivati svoje znanje o predmetu koji predaju; odnositi se prema učenicima s poštovanjem; moći kod njih pobuditi motivaciju za učenje; cijeniti rad i trud učenika, čak i kada to ne rezultira dobrom ocjenom.

Odlučeno je da se može izmjeriti koliko se ispitanik ne ponaša u skladu s normama koje reguliraju njegovu/njezinu profesionalnu ulogu s pomoću pitanja koja započinje sljedećom uputom: Ispod možete vidjeti nekoliko tvrdnji. Molimo, razmislite u kojoj mjeri opisuju posao koji obavljate. Molimo, ocijenite ih skalom od -3 do 3, gdje -3 znači da se uopće ne slažete s navedenom tvrdnjom, a 3 znači da se u potpunosti slažete s navedenom tvrdnjom. U pilot-istraživanju pojavio se problem. Pokazalo se da su, ako su tvrdnje doslovno odražavale sadržaj prije definiranih normi (npr.,Proširujem znanje o predmetu koji predajem"), ispitanici uglavnom označavali samo kategorije koje su upućivale na njihovo potpuno izvršavanje dužnosti. Pretpostavili smo da ti djelomični odgovori dokazuju normativnost tvrdnji. Zbog činjenice da ponašanje u skladu $\mathrm{s}$ obrascima ponašanja donosi određene sankcije, ispitanici nisu bili voljni priznati da su prekršili navedene norme. Stoga je sadržaj tvrdnji modificiran na način da su ispitanici bez bojazni mogli priznati da nisu ispunili određena očekivanja. Na primjer, prije navedena tvrdnja: „Proširujem znanje o predmetu koji predajem“ promijenjena je u: „Nemam vremena proširivati svoje znanje o predmetu koji predajem“. Ta tvrdnja sada sadrži racionalizaciju ponašanja koje nije u skladu s normom, a omogućilo je ispitanicima da se zbog toga ne srame. Podaci iz mjerodavnog istraživanja pokazuju da je skala izrađena na takav način pouzdana. Vrijednost Cronbachove alfe tu je bila $\alpha=$ 0,863, a skala se koristila za mjerenje prosječne razine poštivanja normi (koje reguliraju profesionalnu ulogu nastavnika). Vrijednost te varijable bila je u rasponu od -3 do 3 . Što je bila viša, to je u većoj mjeri određeni ispitanik poštivao norme koje reguliraju profesionalnu ulogu nastavnika.

\section{Osjećaj svrhe}

Također je bilo potrebno operacionalizirati intermedijarne strukture. Na početku istraživanja fokus je bio na scenarijima koji razvijaju osjećaj svrhe u profesionalnoj ulozi 
koju pojedinac ima. Taj se osjećaj javlja kada se zadovolje određene potrebe, uključujući i potrebe višeg i potrebe nižeg reda. Navedena varijabla izmjerena je s pomoću 10 tvrdnji na koje je ispitanik trebao odgovoriti na skali od -3 do 3 , gdje je -3 značilo da se uopće ne slaže s navedenom tvrdnjom, a 3 je značilo da se s njom u potpunosti slaže. Dakle, ispitanici su trebali odrediti pruža li im nastavnički posao: mogućnost stručnog usavršavanja; osjećaj profesionalne sigurnosti; mogućnost za razvijanje vlastitih interesa i hobija; mogućnost da ispune svoju profesionalnu ulogu; zadovoljstvo koje proizlazi iz kontakta s djecom i mladim ljudima; mogućnost da obrazuju i razvijaju mlade ljude; neku vrstu društvenog statusa i osjećaj da ih drugi cijene; financijsko zadovoljstvo te imaju li puno slobodnoga vremena (za sebe i obitelj). Skala izrađena na taj način bila je pouzdana. Vrijednost Cronbachove alfe bila je $\alpha=0,723$. Koristila se za mjerenje varijable osjećaj svrhe u profesionalnoj ulozi koju pojedinac ima. U analizi se koristila prosječna vrijednost varijable, koja je varirala u rasponu od -3 do 3 . Što je bila veća, to je bio jači osjećaj ispitanika da njegov/njezin posao ima smisla.

\section{Negativni i pozitivni odgovori}

Mjerenje intermedijarnih struktura koje aktiviraju nametnuti način ponašanja provedeno je s pomoću dvaju pitanja koja odražavaju ispitanikova uvjerenja o tome koliko je izgledno da: (a) će kršenje prije spomenutih normi naići na negativnu reakciju okoline (školskog odbora, ostalih nastavnika); (b) će poštivanje pravila biti popraćeno pozitivnim sankcijama. Oba pitanja odnosila su se na prije definirane obrasce ponašanja, a ispitanik je trebao odrediti vjerojatnost negativne/pozitivne reakcije na skali od -3 do 3. Obje skale pokazale su se pouzdanima. Vrijednost Cronbachove alfe bila je $\alpha=0,903$ u prvom slučaju i $\alpha=0,898$ u drugom slučaju. Dakle, te skale koristile su se za mjerenja sljedećih varijabli: odgovor okoline na kršenje normi i odgovor okoline na poštivanje normi. Tema analize bile su prosječne vrijednosti varijabli, koje su bile u rasponu između -3 i 3. Što su bile veće, to je bio jači osjećaj ispitanika da kršenje normi ili poštivanje normi izaziva veću reakciju okoline (pozitivnu/negativnu reakciju).

\section{Poštivanje normi od strane drugih}

Intermedijarne strukture, koje su odgovorne za aktiviranje deskriptivnog načina ponašanja, izmjerene su na sličan način - s pomoću 13 tvrdnji koje su se odnosile na prije definirane norme koje reguliraju ulogu nastavnika. Ispitanici su trebali odrediti u kojoj mjeri te tvrdnje opisuju način na koji drugi nastavnici iz škole obavljaju svoje profesionalne dužnosti. Pitanje koje je otvorilo to tematsko područje sadržavalo je informacije koje ističu opći osjećaj ispitanika, a ne daju detaljnu informaciju o njezinu/njegovu radu koja bi zahtijevala dubinsku analizu i refleksiju. Kako bi se utvrdilo koliko je određeni obrazac ponašanja učestao u školi, ispitanici su se koristili skalom od -3 do 3 , gdje je -3 značilo da se dani opis uopće ne odnosi na nastavnike u određenoj školi, a 3 je značilo da opis u potpunosti odražava njihov 
način ispunjavanja profesionalnih obveza. Skala izrađena na takav način pokazala se pouzdanom. Vrijednost Cronbachove alfe bila je $\alpha=0,836$. Skala se koristila za mjerenje varijable: poštivanje normi od drugih. Analiza se bavila temom prosječne vrijednosti, koja je varirala između -3 i 3. Što je bila veća, to je više ispitanik osjećao da nastavnici u njegovoj školi poštuju navedene norme.

\section{Analiza podataka}

Dobiveni podaci uneseni su u SPSS računalni program. Kao prvo, analizirano je koliko spomenuti fenomen utječe na škole uključene u istraživanje. Kako bismo provjerili razlikuje li se prosječna razina poštivanja normi koje reguliraju profesionalnu ulogu nastavnika u tim školama, provedena je jednosmjerna analiza varijance (ANOVA). Ista je metoda primijenjena i u evaluaciji razlika koje možda postoje među školama s obzirom na to koliko nastavnici poštuju pojedine norme i na jačinu intermedijarnih struktura koje na to utječu. S ciljem potvrđivanja hipoteze izrađen je model višestruke linearne regresije $u$ kojoj je zavisna varijabla bila prosječna razina nepoštivanja normi koje reguliraju profesionalnu ulogu nastavnika, a da su nezavisne varijable uključivale osjećaj svrhe u poslu koji nastavnici obavljaju, odgovor okoline na nepoštivanje normi (negativan odgovor), odgovor okoline na poštivanje normi (pozitivan odgovor), kao i poštivanje normi od drugih. Prije provedbe regresijske analize i završne evaluacije modela nezavisne varijable iz ovoga modela stavljene su u korelacijski odnos.

\section{Rezultati}

Na početku je provedena analizira kako fenomen atrofije utječe na tri škole iz grada srednje veličine. Definirana je sljedeća pretpostavka: Prosječna razina nepoštivanja normi koje reguliraju ulogu nastavnika razlikuje se medu nastavnicima koji rade u trima školama odabranima za sudjelovanje $u$ istraživanju. S ciljem prepoznavanja takvih razlika između njih provedena je jednosmjerna analiza varijance (ANOVA). Prema prikupljenim podacima na navedene institucije prije spomenuti fenomen utječe vrlo malo. Prosječna razina poštivanja normi koje reguliraju profesionalnu ulogu nastavnika čini se visokom zato što je dosegnula srednju vrijednost od 1,00. Post hoc testovi (NIR test i Bonferronijev test) pokazali su da postoji statistički značajna razlika $(p<0,01) \mathrm{u}$ jačini te varijable među nastavnicima iz škole A (srednja vrijednost $=1,23$ ) i nastavnicima iz škole $C$ (srednja vrijednost $=0,78$ ). Detaljni podaci o tome prikazani su u Tablici 1.

\section{Tablica 1}

Analiza je također uzela u obzir i koliko su ispitanici poštivali norme uključene $\mathrm{u}$ istraživanje. Pokazalo se da su sastavne dužnosti profesionalne uloge koje su se izvršavale u najvećoj mjeri bile sljedeće: vođenje dokumentacije, pokazivanje poštovanja prema učenicima, zapažanje njihova truda, nalaženje vremena za učenike, 
pripremanje za nastavu, otkrivanje talenata, sposobnosti i predispozicija kod učenika. Čini se da su najveći problemi u izvršavanju obaveza bili povezani s normama koje od nastavnika zahtijevaju održavanje discipline u razredu i poticanje motivacije za učenje kod učenika. Tablica 2 prikazuje podatke o tome prema školama uključenima $\mathrm{u}$ istraživanje.

Tablica 2

Poštivanje pojedinačnih normi od nastavnika iz škola uključenih u istraživanje ( $T=117)$.

\begin{tabular}{|c|c|c|c|c|}
\hline PROFESIONALNE NORME: & ŠKOLA A & ŠKOLA B & ŠKOLA C & UKUPNO \\
\hline - pripremanje za nastavu & 2,05 & 1,76 & 1,79 & 1,87 \\
\hline - vođenje dokumentacije & 2,50 & 2,00 & 2,18 & 2,24 \\
\hline - održavanje discipline u razredu & 0,14 & $-0,06$ & $-0,39$ & $-0,11$ \\
\hline $\begin{array}{l}\text { - objasniti ono što je učenicima teško } \\
\text { razumjeti }\end{array}$ & 0,83 & 1,09 & 0,48 & 0,77 \\
\hline $\begin{array}{l}\text { - naći vremena kada ih roditelj/skrbnik } \\
\text { djeteta treba }\end{array}$ & 1,21 & 0,91 & 0,89 & 1,01 \\
\hline - postupati prema svim učenicima jednako & 0,50 & 0,50 & 0,11 & 0,36 \\
\hline $\begin{array}{l}\text { - naći vrijeme kako bi pomogli učenicima } \\
\text { kada nešto ne razumiju }\end{array}$ & 2,28 & 1,36 & 0,66 & 1,43 \\
\hline $\begin{array}{l}\text { - otkriti u učenicima talente, sposobnosti i } \\
\text { predispozicije }\end{array}$ & 1,59 & 1,21 & 1,04 & 1,28 \\
\hline $\begin{array}{l}\text { - prenijeti znanje učenicima na njima } \\
\text { odgovarajući način }\end{array}$ & $-0,05$ & 0,35 & 0,16 & 0,14 \\
\hline $\begin{array}{l}\text { - proširivati vlastito znanje o predmetu koji } \\
\text { predaju }\end{array}$ & 0,78 & 0,88 & 0,54 & 0,72 \\
\hline - odnositi se prema učenicima s poštovanjem & 2,33 & 1,68 & 1,45 & 1,82 \\
\hline - pobuditi motivaciju za učenje kod učenika & $-0,09$ & $-0,32$ & $-0,20$ & $-0,20$ \\
\hline $\begin{array}{l}\text { - cijeniti rad i trud učenika, čak i kada to ne } \\
\text { rezultira dobrom ocjenom }\end{array}$ & 1,93 & 1,56 & 1,48 & 1,66 \\
\hline
\end{tabular}

Ideja prikazana u teorijskom dijelu upućuje na to da intermedijarne strukture imaju značajan utjecaj na to koliko će osoba poštivati ili ne poštivati norme koje reguliraju njezinu profesionalnu ulogu. Stoga su te strukture postale fokusom pažnje. Analiza je pokazala da je osjećaj svrhe u ulozi koju imaju bio vrlo visok među nastavnicima uključenima $\mathrm{u}$ istraživanje. Slično tome, imali su i visoke rezultate $\mathrm{u}$ sljedećim mjerenjima: odgovor okoline na kršenje društvenih normi (negativan odgovor) i poštivanje normi od drugih. Najmanje su bili uvjereni u to da bi poštivanje obrazaca ponašanja koji reguliraju njihovu profesionalnu ulogu moglo rezultirati pozitivnim sankcijama (uključujući poticaje poput poštovanja u okolini, pohvale itd.). Kako bi se pronašle razlike u sklopu struktura koje možda postoje između nastavnika iz škola uključenih u istraživanje, provedena je jednosmjerna analiza varijance (ANOVA). Zanimljivo je primijetiti sljedeće: odgovor okoline na kršenje normi ili 
odgovor okoline na poštivanje normi varijable su u kojima su se razlike među školama pokazale statistički neznačajnima $(p>0,05)$. Nešto drugačija situacija uočena je kada je analizirana varijabla osjećaj svrhe u ulozi koju nastavnici imaju. Post hoc testovi (NIR test i Bonferronijev test) pokazali su da je razlika u jačini te varijable između nastavnika iz škole A (srednja vrijednost $=1,34$ ) i nastavnika iz škole $C$ (srednja vrijednost = $0,96)$ statistički značajna $(p<0,05)$. Ista situacija vidljiva je u varijabli poštivanje normi od drugih. Isti post hoc testovi pokazali su da je razlika u jačini te varijable između nastavnika iz škole A (srednja vrijednost $=1,10$ ) i nastavnika iz škole $C$ (srednja vrijednost $=0,30)$ statistički značajna $(p<0,05)$. Podaci o rezultatima analize prikazani su u Tablici 3.

\section{Tablica 3}

Potvrda hipoteze istraživanja zahtijevala je razradu modela linearne regresije $\mathrm{u}$ kojem je zavisna varijabla bila razina nepoštivanja normi koje reguliraju profesionalnu ulogu nastavnika, koja je nastala kao rezultat ponovnog kodiranja vrijednosti varijable poštivanje tih normi. Model je uključio i potencijalne prediktore te vrijednosti, a koji odražavaju prije spomenute intermedijarne strukture, uključujući: osjećaj svrhe u ulozi koju nastavnici imaju, odgovor okoline na kršenje normi (negativan odgovor), odgovor okoline na poštivanje normi (pozitivan odgovor), poštivanje normi od drugih.

$\mathrm{Na}$ početku je analizirana vrsta veza između nezavisnih varijabli. Pokazalo se da postoji umjerena korelacija između osjećaja svrhe u ulozi koju imaju, odgovora okoline na poštivanje normi (pozitivan odgovor) i poštivanja normi od drugih. Detaljni podaci o tome prikazani su u Tablici 4.

\section{Tablica 4}

Na kraju su analizirani rezultati višestruke linearne regresije. Pri tome se koristila metoda eliminacije unazad, pod pretpostavkom da bi krajnji model trebao sadržavati nezavisne varijable koje su značajno povezane sa zavisnom varijablom. Rezultati analize pokazuju da su prediktori nepoštivanja normi koje reguliraju profesionalnu ulogu sljedeći: osjećaj svrhe u ulozi koju imaju i poštivanje normi od drugih. Veza između zavisne varijable i osjećaja svrhe u ulozi koju imaju pokazala se umjerenom i negativnom. Ovdje je Pearsonov koeficijent korelacije $r=-0,261(p<0,01)$. Veza između zavisne varijable i poštivanja normi od drugih pokazala se jakom i negativnom. Ovdje je Pearsonov koeficijent korelacije $r=-0,553(p<0,01)$. Što su više ispitanici bili uvjereni da njihov posao nema smisla i da ostali nastavnici u njihovoj školi ne poštuju navedene norme, to je manje bilo izgledno da će i oni poštivati očekivanja koja im nalaže njihova profesionalna uloga. Prediktivna vrijednost modela je velika. Prilagođeni koeficijent determinacije bio je $R^{2}=0,45$. To znači da model objašnjava 45 $\%$ varijance zavisne varijable. Tablica 5 prikazuje detaljne rezultate regresijske analize.

Tablica 5 
Dobiveni rezultati barem djelomično potvrđuju hipotezu istraživanja. Upućuju na to da slabljenje intermedijarnih struktura odgovornih za osjećaj svrhe u poslu i za uvjerenost o poštivanju normi od drugih nastavnika doprinosi onome što se naziva atrofijom profesionalne uloge.

\section{Rasprava}

Istraživanje pokazuje da slabljene intermedijarnih struktura koje aktiviraju deskriptivan način ponašanja i osobni način ponašanja može imati statistički značajan utjecaj na odluke nastavnika da poštuju norme koje reguliraju njihovu ulogu. U prvom slučaju osoba ima dobro utemeljeno ili neopravdano uvjerenje da ostali nastavnici iz škole u kojoj rade ne ispunjavaju očekivanja. Čini se da čak i kada je osoba spremna poštivati norme, postoji problem koji prerasta u oblik rastuće normativne distance. To je zbog toga što osoba sve više percipira razliku između vlastitoga ponašanja i obrazaca ponašanja koji se pokazuju u društvenom okruženju. Rezultat je kognitivna disonanca, zbog čega je naporno održati normativnu distancu. Stoga, ako je nastavnik uvjeren da ostali kolege iz škole ne poštuju norme koje reguliraju profesionalnu ulogu, vrlo je izgledno da će ih i on/ona prestati poštivati. Značajan utjecaj takvih uvjerenja na ponašanje empirijski je pokazan $u$ eksperimentalnim studijama (Cialdini i sur., 1990; Kallgren i sur., 2000).

Čini se da atrofiju potiče slabljenje struktura odgovornih za formiranje osjećaja svrhe u ulozi koju nastavnik ima. To povlači niz pitanja, na primjer o tome koliko škola kao organizacija sudjeluje u cijelom procesu. Ako pretpostavimo da društvo organizira ponašanje svojih članova putem mehanizama društvene kontrole, uključujući i one suptilnije koji utječu na njihova osobna uvjerenja i stavove, rušenje ili podcjenjivanje tih mehanizama može dovesti do slabljenja sposobnosti društva da nađe smisao u nekim aktivnostima. Društvene mogućnosti povezane s aktivacijom i održavanjem struktura koje potiču osobni način ponašanja postaju ograničene. U tom slučaju osoba treba sama pronaći smisao u svom poslu, tj. u ulozi koju ima. Istraživanje pokazuje da, u slučaju nastavnika, poticanje intermedijarnih struktura nastaje, između ostaloga, i kao rezultat pozitivnih sankcija koje mogu očekivati od svoje okoline.

Analiza nije uključila one faktore koji vjerojatno imaju mali ili veći utjecaj na atrofiju. Na primjer, vjerojatno poštivanje i izvršavanje normi od kojih se uloga sastoji može biti ugroženo profesionalnim izgaranjem ili iscrpljenošću, što je posljedica pretjeranih očekivanja na poslu ili profesionalnog opterećenja (Sas i sur., 2011; Springer i Oleksa, 2017). U kontekstu dobivenih rezultata razmišljanja koja su naveli Herczyński i Strawiński (2014) također su zanimljiva. Na temelju podataka dobivenih iz empirijskog istraživanja provedenog na velikom uzorku nastavnika u poljskim školama, izdvojili su nekoliko manjih grupa: ovisni o potpori, profesionalci, radoholičari, mladi entuzijasti i sagorjeli. Osim kod sagorjelih veći problemi koji se odnose na izvršavanje dužnosti koje su sastavni dio uloge mogu se pojaviti i kod predstavnika ostalih grupa, a mogu uključiti i nastavnike iz skupine ovisnih o potpori. Istraživanje 
ne određuje jasno tko su predstavnici te skupine, pa su stoga autori predložili dvije moguće karakteristike tih nastavnika. Prema jednoj oni se ne angažiraju previše u radu u školi i možda razmišljaju o promjeni posla, pa smatraju da je izvršavanje profesionalnih dužnosti gubitak vremena. S druge strane, postoji i pretpostavka da se te osobe osjećaju ugodno u nastavničkoj profesiji i posvećuju poslu onoliko vremena koliko se to od njih traži. Druga su grupa sagorjeli koji, u usporedbi s drugima, osjećaju da su preopterećeni poslom i vide manju svrhu u poslu i načinu na koji ga obavljaju (Herczyński i Strawiński, 2014, str. 34-36).

$\mathrm{Na}$ kraju, analiza nije uključila faktore koji se tiču rukovodstva i organizacije rada u školi. Pod pretpostavkom da intermedijarne strukture uglavnom nastaju kao rezultat strukturnih učinaka, trebalo bi ih se uzeti u razmatranje i tako obogatiti razmišljanja o atrofiji. Analiza dobivenih podataka pomogla nam je uočiti statistički značajne razlike na razini poštivanja normi, ovisno o školi u kojoj ispitanici rade. Stoga postoji vjerojatnost da aktiviranje individualnog načina ponašanja može ovisiti o odnosima između nastavnika i njihovu odnosu sa školskim odborom i učenicima. Bilo bi korisno razmotriti utječe li na intermedijarne strukture i izvršavanje obaveza od kojih se profesionalna uloga sastoji neučinkovita postfeudalna organizacijska kultura, koju je opisao Hryniewicz, a koja je tipična za zemlje središnje i istočne Europe te koja možda postoji barem u nekim školama u Poljskoj (Hryniewicz, 2007).

\section{Zaključci}

Cilj istraživanja bio je prepoznati odrednice atrofije u trima osnovnim školama u gradu srednje veličine u Poljskoj. Pretpostavka je bila da bi slabljenje intermedijarnih struktura između obrazaca ponašanja i stvarnog ponašanja osobe trebalo imati značajan utjecaj na nepoštivanje normi koje reguliraju profesionalnu ulogu nastavnika od samih nastavnika. Rezultati istraživanja pokazuju da što je veća deaktivacija osobnog načina, koji se sastoji od struktura koje razvijaju osjećaj svrhe u profesionalnoj ulozi koju nastavnik ima, i deskriptivnog načina, koji se temelji na strukturama koje definiraju normativnu distancu, to je osoba više sklona neizvršavanju dužnosti koje su sastavnice njezine profesionalne uloge.

Iako je atrofija poželjan proces kada je ponašanje pojedinca organizirano na disfunkcionalan način, taj je fenomen obično negativan jer sprečava stvaranje normativnog kapitala koji bi bio pogodan za ispunjavanje kolektivnih ciljeva $\mathrm{u}$ zajednici ili u društvu. Stoga se čini razumnim definirati čimbenike koji utječu na slabljenje intermedijarnih struktura i točno odrediti koliko taj proces ovisi o školama i metodama organizacije rada koje se u njima primjenjuju. 